Relations industrielles

Industrial Relations

\title{
Continuity and Change in Australian Industrial Relations
}

Recent Developments

Continuité et changements récents dans les relations

industrielles en Australie

Continuidad y cambio en las relaciones industriales en

Australia

Desarrollos recientes

Ian Hampson et David E. Morgan

Volume 53, numéro 3, été 1998

URI : https://id.erudit.org/iderudit/005284ar

DOI : https://doi.org/10.7202/005284ar

Aller au sommaire du numéro

Éditeur(s)

Département des relations industrielles de l'Université Laval

ISSN

0034-379X (imprimé)

1703-8138 (numérique)

Découvrir la revue

Citer cet article

Hampson, I. \& Morgan, D. E. (1998). Continuity and Change in Australian Industrial Relations: Recent Developments. Relations industrielles / Industrial Relations, 53(3), 564-591. https://doi.org/10.7202/005284ar

Tous droits réservés (C) Département des relations industrielles de l'Université Laval, 1998
Ce document est protégé par la loi sur le droit d'auteur. L'utilisation des services d'Érudit (y compris la reproduction) est assujettie à sa politique d'utilisation que vous pouvez consulter en ligne.

https://apropos.erudit.org/fr/usagers/politique-dutilisation/ 


\title{
Continuity and Change in Australian Industrial Relations
}

\section{Recent Developments}

\author{
IAN HAMPSON
}

School of Industrial Relations and Organisational Behaviour, University of New South Wales, Sydney, Australia.

DAVID E. MORGAN

School of Industrial Relations and Organisational Behaviour, University of New South Wales, Sydney, Australia.

The recent accession to power of a conservative (Liberal) National Coalition) government in Australia would seem to mark a major change -- perhaps a transformation -- in Australian industrial relations. However, a more subtle reading of events suggests that key ingredients of the new government's reform package were actually foreshadowed, even partially implemented, by the former Australian Labor Party government. The latter was well known for its enthusiastic implementation of orthodox economic policies, albeit in a context of 'corporatism'. This suggests a degree of continuity between the policies of the ALP and Liberal/National Coalition governments. At the same time, there are ingredients of significant change, some of them on the face of it minor, but which, over time, are likely to erode the power of unions and sharpen the divide between the union and non-union sectors.

In the 1980s and early 1990s, Australia, along with most other AngloAmerican nations, experienced deepening pressures to reconfigure its industrial relations arrangements to conform to neo-liberal notions of labour market 'flexibility' (see OECD 1986). In Australia's case, these pressures were exacerbated by trade and financial liberalization undertaken in the 1980s, since it was felt that industrial relations was increasingly poorly aligned with the changes in the rest of the economy. What was distinctive about this series of changes, in international comparative terms, 
was that the major deregulatory reforms, inspired by international economic orthodoxy, were undertaken by an ostensibly social-democratic party -- the Australian Labor Party (ALP) (Kelly 1994: 23). More specifically, according to a widely received view, unions were allegedly 'involved' in the processes via 'corporatist' arrangements, and were therefore able to influence the outcomes in a manner favourable to their constituency (Kyloh 1989, 1994; Archer 1992, 1995). But a more subtle reading of this period finds that this politically unusual configuration -union involvement in the development and implementation of neo-liberal public policies - contained some sharp contradictions.

First, while the stability of the 'corporatist' arrangements depended on the traditional union enforcement of membership discipline, continuing wage restraint placed inordinately high expectations on the outcomes of the policy processes to deliver quid pro quos. Second, these were not delivered by neo-liberal economic reforms, which simply created increasing economic instability for workers, raising the question of why workers and their representative organizations should support such changes. After 1987 , as the focus of reform shifted to industrial relations, workplace change and 'flexibility', these contradictions became more acute, and expressed themselves in a crisis of legitimacy for the union movement. Consequently, prior to its political collapse, the legitimation limits of what might well be called 'neo-liberal corporatism' were exposed - the decline in union density, disenchantment with union workplace representation and national union leadership and, finally, the weakening of working-class voters' allegiance to the ALP (Hampson 1996). Only an inept 1993 election campaign by the conservative parties saw the Labor Party returned to office for a further three-year term (Kelly 1994).

However, on March 3, 1996, the deep contradictions of Australian corporatism came to a head, as voters decisively rejected the ALP in favour of the conservative Liberal/National Party Coalition. ${ }^{1}$ At the centrepiece of the Liberals' reform program was a proposed Workplace Relations (and other) Amendment Act, although little was known about it at the time. The Liberals had kept as much policy detail from the Australian electorate as possible, hoping to capitalize on the discontent with Labor and to avoid the criticism that they sought economic growth and profits through further attacks on working-class living standards. But in mid-1997, Prime Minister Howard made clear his admiration of the US model of labour

1. In contrast to North American usage, the term 'liberal' in Australian political terminology refers to a political party that has a strong conservative lineage, making it suitable to operate in coalition with the National party, the latter having a rural constituency. Political battles within the Liberal party, between social conservatives and the reforming radical right, were decisively won by the latter in the 1980s. 
market flexibility, complete with heightened labour mobility, low union density, lower wages and an abundance of peripheral sector 'McJobs' to soak up the unemployed. Howard echoed economic orthodoxy's 'Eurosclerosis' analysis, according to which labour market 'rigidities' (for which read strong unions and effective state employment regulation) impeded the capacity of labour markets to clear at low rates of unemployment (Fels and Fuerstenberg 1989; Grahl and Teague 1989: 91-92; Nielsen 1991: 4). Howard pointed out how European industrial relations institutions improved conditions and job security for those in employment, but at the price of higher overall unemployment. Australia's industrial relations institutions, said Howard, more closely resembled European ones, with resulting high unemployment (between 8.5 and 8.8 percent). The course of industrial relations reforms pursued by the Liberals in power has reflected these policy preferences. However, the reforms have been restrained by political and institutional inertia, which stems from the Australian federal political structure.

This article argues that there is in fact more continuity between the economic and industrial relations policies of the former and incumbent governments than appears to be the case at first glance. This is in part due to long-standing features of Australian federal politics, which give the Senate - an upper house of review, elected by a state-based proportional representation system -- significant powers. This has prevented the government from fully implementing its preferred course of reform. In 1996, the legislative and policy details of the new government's programs were fought out in the public arena and in the Senate, where the government had to negotiate with minor parties and independents to gain passage of its legislation. Many of the changes were also greeted by protests, demonstrations and strikes. It remains to be seen how the new legislation comes into play. Key elements of the legislation will go before the High Court for rulings on constitutional issues, and the parties have indicated an increasing inclination to litigiousness. There is likely to be ongoing industrial relations instability, as employers and the government use the new legislation to attack union power in key sectors, notably the waterfront, mining, transport and construction sectors, and the public service.

Our argument proceeds as follows. In the first section, the background to Australia's current period of industrial relations turbulence is examined. The section also sketches industrial relations under the peculiar variant of 'corporatism' that grew up from 1983, when the ALP last assumed power. The second section focuses on industrial relations reform under the Liberal/National coalition, describing the Liberals' intentions as they were revealed in the immediate aftermath of the election, and the popular opposition they excited. The section goes on to examine the final 
form of the legislation in some detail, revealing how the Liberals were unable to implement their preferred reforms in their entirety. The third section describes the union strategies that have emerged in this situation, while the fourth examines the points at which industrial relations instability is likely to occur. The conclusion establishes that there is more continuity between the industrial relations policies of the ALP and the Liberal/ National coalition than appears to be the case at first glance, and that the inertia in Australia's political institutions makes radical industrial relations change less likely than in some other countries where cabinet government is less constrained by multiple checks and balances.

\section{BACKGROUND}

\section{The Former System: Industrial Relations Under 'Domestic Defence'}

Briefly, Australia's industrial relations system were somewhat unusual, even unique, in international terms, being characterized by a compulsory arbitration system established at both federal and state levels between 1900 and 1915. This system has been under challenge since the late 1980s (Blandy and Niland 1986). Frances Castles (1988) declared that Australia was 'between historic compromises', as economic and political change had eroded the accommodation between producer groups by the early 1900 s, but that a new one had not yet been worked out. There is some consensus that Australia was for too long inward looking, xenophobic and protectionist, with an industrial relations system linked into an inefficient manufacturing sector. The economic structure was supported by a vibrant primary sector, which exported wool, wheat and dairy products to Britain. When the latter markets all but disappeared after Britain's entry into the European Community, the whole political-economic structure was called into question.

Castles (1988) has noted how Australia does not fit within the taxonomies of mainstream comparative political economy, developed by Katzenstein $(1978,1985)$ and others; and he has referred to the 'Antipodean Exceptionalism' of the Australian and New Zealand political/economic arrangements. Castles (1988) uses the concept of 'domestic defence' to capture the interlocking nature of the political-economic arrangements around a core of measures designed to protect society against disruption from economic competition and immigration. A political coalition between labour interests and domestic manufacturers at the expense of pastoralists gave this legislative expression at the turn of the century. One of the first Parliament's first acts was to restrict immigration via the socalled 'White Australia' policy. Protection was then extended to manufac- 
turing industry, provided that industry paid fair wages, determined in a Conciliation and Arbitration Commission (lately referred to as the Industrial Relations Commission). This linkage was called "new protection", and was necessary for the "wage earners' welfare" pursued by the labour movement (MacIntyre 1986; Castles 1985). Australia's constitution empowered the Australian Industrial Relations Commission (AIRC) (or its predecessors) to regulate industrial relations in so far as they are defined as 'industrial' and national (i.e., of an 'interstate' nature). The AIRC has powers to approve industrial agreements, to make determinations regarding industrial disputes and other industrial matters and, more recently, to certify different categories of enterprise agreements. These rulings and the minimum terms and conditions of employment were formerly most often expressed in 'awards', which were legally enforceable documents prescribing wages and conditions of work, and which still cover about 85 percent of the workforce, despite inroads made by other forms of employment regulation. Thus the Commission could (through 'National Wage Cases') affect the wages of most workers at a stroke. The historic 1907 Harvester Judgement of the President of the then Conciliation and Arbitration Court, Mr. Justice Higgins, invoked the principle that wage levels should not be determined solely on the basis of market forces, or through the cut and thrust of class conflict, or by differentials in skill, but rather in the quasi-judicial arena of the Court according to notions of social need (Dabscheck 1994).

The wages and conditions of employees were set under both federal and state awards. In the federal system, coverage was automatic if the employer or its representative was a signatory to the award, and the states used 'common rule' awards that automatically cover all employees in a given occupation, industry or business sector. Thus employees did not need to be union members to gain the benefits of award regulation of their conditions of employment, but union preference clauses 'encouraged' union membership. Moreover, the 'conveniently belong' rule regulated inter-union competition by allocating new members to existing unions on the basis of either occupational boundaries, or historic job territory. Union density reached 60 percent in 1951 and remained stable around 50-55 percent until the 1980s. However, density has declined precipitously through the late 1980s and into the 1990s under ALP rule, from 46 percent in 1986 to 31 percent in August 1996 (ABS 1996) and this is obviously a central concern of union strategists (e.g., Berry and Kitchener 1989; Evatt Foundation 1995). Thus through most of this century the link between density and coverage (around 55 percent and 85 percent respectively) was stronger than during the 1990s (see table 1). Through the 1980 s, the arbitration and award system was strongly criticized by 
employer groups and a so-called 'new Right' (Dabscheck 1989) as a mechanism that extends the results of collective bargaining to non-unionized employees, thus violating the rights of individuals to determine their own employment conditions. These groups sought the possibilities of non-union and non-award 'employee relations', and by implication favoured the narrower gap between density and coverage evident in the last four countries in table one rather than the relationship of the European, especially the German, model.

TABLE 1

Collective Bargaining and Union Density (estimates, early 1990s)

\begin{tabular}{lcc}
\hline \multicolumn{1}{c}{ Country } & $\begin{array}{c}\text { Collective Bargaining } \\
\text { Coverage (\%) }\end{array}$ & Union Density (\%) \\
\hline Australia & 85 & $30-35$ \\
Denmark & 95 & $85-90$ \\
Sweden & $90+$ & $90+$ \\
Germany & 90 & 35 \\
Netherlands & 80 & $25-30$ \\
France & $70-80$ & 10 \\
United Kingdom & 55 & $40-45$ \\
Canada & $40-45$ & $35-40$ \\
USA & $20+$ & $13-18$ \\
Japan & $20-25$ & $20-25$ \\
\hline
\end{tabular}

Source: based on R. J. Adams, "Industrial Relations under Liberal Democracy: North America in Comparative Perspective" quoted in Bean (1994: 78).

A further complication is that this system of industrial relations covers nine jurisdictions (states and territories) in which there is considerable duplication as well as differences. The federal jurisdiction includes industrial issues covering two or more states, although again over time, High Court rulings on the application of the interstate test have broadened. Under the Constitution, federal legislation overrides that of the states, and conflicts continually erupt over the practical effect of particular provisions. Thus conflicts between state and federal approaches to industrial relations, as with other policy arenas, are abiding facts of Australian political life.

\section{Industrial Relations Under 'Corporatism'}

The collapse of Australia's erstwhile accommodation between manufacturing and organized labour was ushered in by increasing consensus around the merits of neo-liberal economic policies. This consensus ini- 
tially took shape in the bureaucracy from the early 1970s (ironically under a short-lived reforming ALP Government) and acquired greater hold over policy making under the Liberal/National coalition from 1975 till 1983 (Warhurst 1982). However, the political exhaustion of the coalition was revealed in its inability to implement neo-liberal reforms with which (apart from its socially conservative wing) it held considerable ideological affinity (Kelly 1994). Thus the task of economic reform fell, once again, to a newly incumbent ALP government, ironically brandishing its 'special relation' to the union movement, which emerged from the late 1970s, to electoral advantage. This 'special relation' ushered in a period of policy experimentation under 'corporatist' arrangements, the documentary expression of which was a series of 'Accords' between the ALP and the Australian Council of Trade Unions (ACTU) (Stilwell 1986; Ewer et al. 1991).

The Commission's powers to make across-the-board wage adjustments and changes to Awards, in particular in 'National Wage Cases', was the key to the ALP government's wages policy. Australia's peak union body, the ACTU, would negotiate with the government, trading off wage restraint for influence on other policies (notably taxation, social welfare, health, training and industry policy), and both parties would take an agreed position to the AIRC Commission. This process of political bargaining, most analysts would agree, enabled an unusual degree of wage restraint and industrial peace, and, on the employers' side, increased profits (Matthews 1994). The early years of the Accord (till about 1989) also saw greater employment growth than would have obtained in the Accord's absence (Stilwell 1986).

On economic policy, the ALP was far more radically reformist than its Liberal predecessors. Viewed from outside, Charlotte Yates (1996) has noted the increasing influence of economic liberalism - known as 'economic rationalism' (Pusey 1991) - which is "about a new vision for the future of Australia, a vision that involves a rejection of past economic, political and cultural traditions in favour of a new path that is competitive, Asia centred and individualistic" (Yates 1996: 628). These ideas quickly acquired a stranglehold on internal ALP policy processes (Edwards 1996). The ALP implemented a number of reforms that, over its time in office, fundamentally changed the Australian economy and society (Beilharz 1994; Kelly 1994). The sweeping liberal economic reforms included allowing the value of the Australian dollar to be determined by 'market forces' ('floating' the dollar), welcoming competition by foreign-owned banks in a newly deregulated financial sector, lifting restraints on foreign ownership and investment, and dismantling the walls of tariff protection that 
had sheltered Australian manufacturing since its inception (Davidson 1992; Ravenhill 1994).

From the mid-1980s, the content of the Accord processes became increasingly focussed on work reorganization and industrial relations reform, as economic commentators and political actors took the view that economic deregulation implied dismantling the Australian experiment with centralized wage determination in favour of US-style labour market flexibility. Thus, reforms enacted by the ALP, accepted by the ACTU, but influenced by Australia's Business Council (a policy advocacy group representing the interests of Australia's largest corporations, chiefly in mining and finance) were increasingly aimed at replacing the centralized wage fixing system with a new system of 'enterprise bargaining' (BCA 1989; O'Brien 1994). The economic shocks of 1986-87 - the collapse of the Australian terms of trade and rising current account deficit - also pushed the Accord 'partners', sanctioned by the AIRC, to adopt innovative methods to link wages closely to industry and enterprise productivity. In several decisions from 1987 to 1989, the AIRC adopted a 'two-tiered' wage system combining fixed dollar increases with productivity-linked percentage increases (Hancock and Isaac 1992). This departure from long-standing 'solidaristic' wage fixing principles was the first step in the 'flexibilization' of the Australian labour market, a process that would give rise to enterprise bargaining. Much of the contest over the shape of Australia's industrial relations system in the 1990s concerned the shape 'enterprise bargaining' would take (Dabscheck 1995).

Almost immediately after the re-election of the ALP to a record fifth term, the relationship between the ACTU and the ALP became strained by ALP proposals to permit non-union enterprise bargaining. This was a major policy battlefield through 1993, as Prime Minister Keating and Industrial Relations Minister Brereton favoured industrial relations reform measures strikingly similar to those of the new 1996 Liberal/National Coalition Government, notably provision for non-union employment contracts and for narrowing the award system to a few core conditions. In the resulting trade-off, the Industrial Relations Reform Act 1993 (IRR Act) represented a smaller step than the ALP leadership desired in what was by now seen as an inevitable decentralization process. The Act, which came into operation in March 1994, included two key changes: the provision for non-union, non-award bargaining; and the importation into the Act of several ILO Conventions on labour issues. The conventions covered issues such as minimum wage setting, equal pay, anti-discrimination, unfair dismissals, equal opportunity for workers with family responsibilities and others (under Schedule 1, IRR Act). Using the External Affairs power of the federal constitution, the Labor government attempted to incorporate 
developments in anti-discrimination and equal opportunity directly into industrial relations regulation for the first time. The Act also added a new Bargaining Division to the AIRC (IRR Act, par. 170MK(1)(a) Division 5A) to administer Certified Agreements (CAs) with unions, and non-union Enterprise Flexibility Agreements (EFAs). In addition provision was made for 'flexibility clauses' (IRR Act, ss.113A and 113B) to be inserted into existing awards. Critically, the EFA procedures permitted union intervention at the stage of ratification by the AIRC. The relevant union had to be notified and could register and present its objections to proposed agreements. More than 5,000 CAs were completed or in train by early 1996 and dramatically fewer EFAs.

The ALP's reform program, including industrial relations reforms, cut into the wages and conditions of workers, and was ultimately an important contributing factor to a decline of union membership and loss of core support for the ALP. Many union members came to see little benefit from their membership, and little reason to vote for a government that was cutting their living standards. Although there is some disagreement about this interpretation (e.g., Peetz 1996), this is certainly the view of the ALP's own election post-mortem (Federal Campaign Consultative Panel 1996). The new Liberal/National Coalition government is taking a new tack with industrial relations by promptly ending the Accord and adopting a more confrontational approach designed to reduce the power of unions even further. However, it could be argued that the new government's stance is different only in degree - that is that the new government is simply offering a stronger dose of the same medicine as the ALP.

THE LIBERAL NATIONAL COALITION AND INDUSTRIAL RELATIONS REFORM

If Labor's political success was due to silencing the Left and capturing the electoral middle ground (and then moving that ground to the right), as many commentators believe, the consequence was to push the Liberals further to the political right. However, in the 1993 election, this rightward shift ultimately clashed with Australia's longtime conservatism. Confounding predictions, the Liberal/National Coalition under the leadership of John Hewson, a former economics professor, lost what was dubbed an 'unloseable' election. While the electorate was clearly angered and disenchanted with Labor, Hewson's campaign program of radical 'Liberal' economic reform, in particular an 'economically responsible' but electorally feared broad-based consumption tax, eventually so frightened the electorate that they turned back to Labor (Kelly 1994). Consequently the Liberal election campaign of 1996 was characterized by an 
approach which sought above all to avoid 'frightening the horses'. The 'new' leader John Howard's ${ }^{2}$ 'vision' was of a 'relaxed and comfortable' Australia, and he promised moderate reform in the sphere of industrial relations as in other policy areas. In 1993, Labor could point to Hewson's open desire for radical labour market reform that threatened workers' interests more than Labor's programs did. But in 1996, the Liberals were more subtle, even promising that 'no worker would be made worse off' as a result of their industrial relations reforms. A host of other similar electoral promises were made - not to cut health care, education, or welfare. The strategy worked, and Labor was swept from office. An historically high proportion of voters deserted the ALP in previously safe Labor electorates, particularly in the largest state of New South Wales. This has significantly weakened both the ALP and the union movement, at least through 1996 and the medium term.

Once in power, however, the Liberals' promises proved expendable, as they were redefined as 'core' and 'non-core' promises, where the latter could be broken if circumstances required. Thus many commitments were jettisoned quite brazenly, since, according to the Liberals, the federal government's accounts were in deficit to the tune of $\$ \mathrm{~A} 8$ billion. This would have to be made good through 'fiscal consolidation' -- or cuts to the public sector. At the same time, the nation's poor performance in employment and trade would have to be improved through industrial relations reform, in particular on the waterfront, in transport and mining, and in the public service. However, peculiarities of Australian politics would stymie the reforms. Despite their sweeping victory, the Liberals had failed to gain a majority in the Senate, the consent of which is required to pass all legislation. This situation is not unusual in Australian politics, and in recent times alternative parties and independents have gained increasing presence in the Australian political system, capitalizing on the Senate's proportional representation system. Under this system voters can vote for one party in the lower house and a different one in the upper house, thus allowing the electorate to experiment with alternatives or to 'take out political insurance' against excesses of untrammelled cabinet government.

\section{Industrial Relations Reform}

Industrial relations reform would prove to be among the most highly contested arenas of the new regime. Shortly after gaining power, the new

2. Howard had been Treasurer under the Fraser Government (1975-1983), and had been Opposition leader until deposed by Andrew Peacock. He retook the Liberal leadership from Alexander Downer in 1995. 
administration put forward its 'ambit claim'. The Workplace Relations (and other) Amendment Bill represented a major shift in the philosophy of Australian industrial relations - from a stance which recognized the fundamental inequality in bargaining power of labour and capital, and therefore the legitimate role of external agencies in employment regulation (pluralism), to one which posited an equality of parties to the bargaining relationship, and therefore that the best results would be obtained through their 'freedom' to set the conditions best suited to their specific circumstances.

Thus the Bill proposed stripping back the award system, from a comprehensive system of employment regulation, to a minimal set of core conditions. It also proposed a new system of confidential individual employment contracts to be known as Australian Workplace Agreements (AWAs), outside the regulation of the Industrial Relations Commission. The latter's role was to be limited to administering disputes over the core conditions, and other matters. It could order strikers to return to work (or employers to lift a lock-out), and failure to comply would swiftly render strikers and unions liable to injunctions, penalties and criminal action administered through the courts. Strong prohibitive measures against secondary boycotts were to be reintroduced, and the Act aimed to prevent primary industrial action that interfered with the international (perhaps even internal) movement of goods. In addition, Labor's legislative supports for the Super Unions, or amalgamated structures built up under Labor's rule, were to go. Abolishing the 'conveniently belong' rule would give employees freedom of choice to belong to a union or not. Taken together, these measures would usher in a new era of interunion competition for a declining membership base, further disarming the union movement. In the same vein, union delegates were to be denied automatic right of entry to workplaces and requiring a written invitation from an employee. The Bill also proposed allowing employers to bypass unions and deal directly with employees at the bargaining stage, opening the possibility of US-style deunionization drives. The Bill would abolish Labor's prohibitions on 'unfair dismissals', and significantly increase employer prerogatives in this area.

Commentators immediately attacked the proposed Bill as strengthening the hand of employers to an unreasonable extent. Of particular concern was the Act's potential effects on women, the young and others potentially disadvantaged in pure labour market competition. One of the effects of Labor's reforms had been to increase the level of wage dispersion within the economy, and to accelerate the 'hollowing out' and 'polarization' of the labour force into a core of well paid, if overworked employees, and a 'periphery' of underpaid, less secure and casualized 
workers. While the labour force participation rate of women has continued to rise in the 1980s and 1990s, women are disproportionately represented in the peripheral labour market. Indeed, under Labor most employment growth took place in part-time and casualized jobs (DIR $1995,1996)$. It was feared that the new legislation would only accelerate this trend, as women would be disproportionately forced into the AWA stream. Also, many workers lacking labour market strength would find their conditions being eroded. Thus, much concern was expressed at the Liberals' proposed industrial relations reforms.

\section{Other Reform Proposals}

These reform proposals were, however, only part of a series of policy announcements driven by the desire to cut back on public expenditure, and which attacked many interest groups, through health, education, welfare, Aboriginal affairs, and of course the unions. In August 1996, these interest groups organized a large demonstration which 'got out of hand' and became violent; unruly demonstrators forced their way into Parliament House and ransacked a souvenir shop. Prime Minister Howard quickly secured useful television footage walking among the blood and broken glass, vowing not to be swayed by 'extremists'. The situation put the ACTU in a difficult position, caught between the need to publicly condemn the violence, yet wishing to capitalize on the public show of opposition. Ultimately, the ACTU was forced to root out 'troublemakers' from its own ranks. From that time on, it appears that political opposition to the Workplace Relations Bill began to fade.

The key group with which the government had to deal in the Senate was the Australian Democrats, who held the balance of power and who intended to hold the Prime Minister to his election promise that no worker would be disadvantaged as a result of the new legislation. The Democrats deferred the Bill to a Senate Committee of Inquiry, which took submissions from around the country on the likely effects of the legislation. However, the Democrats' privileged position was undermined in one of those serendipitous events that from time to time tip the balance in Australian politics. Labor Senator Mal Colston was denied the Deputy Presidency of the Senate by the ALP, and promptly resigned (from the ALP, not the Senate) in protest, thereby becoming an independent. The Liberal/National coalition ensured that Colston was given the position, possibly on the basis that Colston would vote with the Liberals on crucial legislation, despite vigorous denials of any such deal. However, while Colston was open to other aspects of the Liberal's agenda (like the part-privatization of Telstra, the publicly owned telecommunications carrier) he was less inclined to support the Workplace Relations Bill, although it was not cer- 
tain that he would not. ${ }^{3}$ Meanwhile, a by-election win was interpreted as reaffirming the Liberals' 'mandate' for reform, and Howard urged the minor parties and independents in the Senate to 'get out of the way' of the government's industrial relations reform agenda. These pressures drove the Democrats to a compromise.

\section{The Workplace Relations (and other) Amendment Act}

The compromise Workplace Relations (and other) Amendment Act, 1996, which became law on January 1 1997, differs significantly from its initial version, and retains many features of the old system of industrial relations - to the extent that commentators on the Right see the Bill as a missed opportunity. Supporting the thesis of continuity, the Act is an amendment to Labor's Industrial Relations Act, 1988. Moreover, some of the 1996 proposals were advanced by the Labor leadership after the 1993 election, although as we noted above they were amended under union pressure. In particular, although it was desired by the ALP leadership, Labor's 1993 legislation did not limit the scope of issues covered by awards, but merely permitted the possibility of 'flexibility clauses' to be inserted into or added to awards. While the legislation permitted nonunion 'enterprise flexibility agreements', the process of certification allowed unions to intervene and present information to the Commission regarding possible disadvantage to employees by undercutting awards. A 'no disadvantage test' allegedly prevented employees losing conditions though non-award agreements. These procedures discouraged more aggressive employers wishing to avoid public scrutiny, by providing a forum to expose their practices.

In summary, the Act's main features are as follows.

Australian Workplace Agreements (Part VID) and Certified Agreements (Part VIB)

The most significant feature of the Act is the way it has, for the first time, opened up a stream of individual or collective contracts outside (or largely outside, as we will see) the formal arbitration machinery, contracts that can override collective agreements and awards. These are known as Australian Workplace Agreements (AWAs), and the provisions for Enterprise Flexibility Agreements under the 1993 amendments are repealed. The AWAs are to be filed with a new Office of the Employment Advocate

3. Colston's fate was that he was hounded by the ALP over abuses of his travel accounts, and resigned the Deputy Presidency on the eve of police intervention. He still sits in the Senate and, resentful that the government failed to protect him, often votes against it. Police action is proceeding, however, and if Colston is forced from the Senate, according to the Constitution, his seat would revert to the ALP. 
(Part IVA; VID, Div 4). Under the original version of the legislation, these agreements were to be confidential, and beyond the scrutiny of unions and the AIRC. The right of redress in respect to compliance was to be via civil action through the Office of the Employment Advocate (OEA), although it was unclear exactly how -- the proposal seemed to see the Office as a simple referral agency and a filing cabinet for the new agreements. In its final form, AWAs are to be checked by the OEA and approved if there is no 'doubt' that their content does not breach a 'no disadvantage test' (see below). If such doubt exists, the OEA is to refer the proposed agreements to the AIRC for private review and recommendations or rejection. AWAs can be negotiated with employees on an individual or collective basis, but must be signed individually. Crucially, there is no union right of involvement or intervention in the process.

Certified agreements (Part VIB) are collective agreements, which may or may not involve unions, and they will be certified by the Industrial Relations Commission, once again subject to a no disadvantage test. The intention of the initial proposed regulation of union-based Certified Agreements (CA) was to break the present linkage between such agreements and awards. It was therefore proposed that CAs be limited to seven minimum conditions, including that there be no reduction in pay when compared to awards. While some discussion has developed over the practical application of this provision, the final Act was much broader and has tended to overshadow this issue. The no disadvantage test in respect to the award now applies to CAs -- and thus covers the same, albeit narrowed, scope of award issues (Part VIE). The AIRC must also ensure that the interests of workers in a disadvantaged bargaining position (e.g., migrants and young workers) and those unfairly excluded from the agreement itself are taken into consideration in the approval process. The aim of the legislation is to emphasize single-employer agreements, but limited multi-employer agreements are possible. Unions are only to be involved if employees request it. Both AWAs and CAs are legally binding agreements, made for fixed terms, that contain prohibitions on industrial action during the life of the agreement. Such action is only 'protected' during a short interim period between the expiry of an old agreement and the negotiation of a new one.

\section{Awards (Part VI, Div. 3)}

Despite downgrading its importance, the award system remains a crucial element of employment regulation, particularly for the AIRC to deliver across-the-board wage increases that target low-paid workers. The original version of the Act proposed 'stripping back' awards to a set of core minimum conditions (initially only six or seven), rather than a pri- 
mary mechanism for regulating the broad range of wages and conditions. In particular, 'paid rates' awards were to be abolished. The role of the Industrial Relations Commission was to be restricted to those core areas. The final version of the Act retains a more significant role for awards, in particular through the 'no-disadvantage' test. The test is of a 'global' nature, which balances all employee gains and losses. The test appears not to allow award conditions to be undercut by certified agreements or AWAs. As noted, where the OEA suspects that a proposed AWA falls short of award conditions, on the global test, it can refer the matter to the IRC for review. Thus there still remains a considerable role for the Award system. The scope of awards is wider than the originally proposed version of the legislation - covering '20 allowable matters', including superannuation, variations to hours and breaks, career paths, and outworkers. The process of simplifying awards is envisaged as taking about 18 months. We are yet to see what the restriction of award regulation will mean in practice, since some unions have successfully incorporated award provisions in new enterprise agreements, and secured employer commitments not to proceed with award simplification. Once again, almost exactly the same proposals were made by Prime Minister Keating soon after his reelection in 1993, although opposition by the unions prevented their implementation.

The Australian Industrial Relations Commission and Industrial Action (Parts II, VI)

The Commission thus retains a more significant role than the original legislation envisaged. The final act has retained the ability of the AIRC to arbitrate on exceptional matters (beyond those specified in the Act) where agreement has not been reached or otherwise harsh or unjust outcomes would result. The AIRC has also retained jurisdiction over the issue of 'equal pay for work of equal value', which has been a major factor in closing the gender wage gap in Australia over the last thirty years (although the latter started to widen under the ALP's version of enterprise bargaining). These provisions offer considerable scope, in theory, for the Commission to retain an activist role in the union stream of the regulation of wages and conditions of employment. The extent to which the Commission is willing to exercise these provisions or is permitted to under future amendments from the government is yet to be seen.

Apart from underpinning award regulation as described above, the IRCs centrality to dispute resolution via conciliation and arbitration is assured (Part VI). Arguably, under the new legislation its power is even strengthened through its ability to order participants in disputes to desist from strikes or lockouts. Thus, despite the existence of a new legislated 
right to strike under certain conditions (in negotiation over the terms of a new agreement, for example), 'non-protected' industrial action will quickly encounter significant legal restraints. Strikers who defy Commission orders (a regular practice in Australian industrial relations since 1969) can be met with injunctions issued by the Federal Court, and fines or jail for non-compliance.

Of particular concern to many commentators is the treatment of secondary boycotts. Labor moved these provisions (Ss 45D \& 45E of the Trade Practices Act), which dated back to the 1970s, directly into Industrial Law (to the Industrial Relations Act, 1993 Part 6), and removed the immediate threat of pecuniary and criminal action in the legitimate exercise of industrial rights. The Coalition has reinstated strong secondary boycott prohibitions and exposed workers to pecuniary action under Common law (by transferring these provisions back to the Trade Practices Act). The Act also apparently defines primary industrial action that involves the movement of goods and overseas trade as a secondary boycott, thus exposing it to legal action by employers. In the initial version of the Act, actions by unions and community groups to protect the environment, human rights or consumers (actions that inhibit the flow of goods or services) were deemed to be secondary boycotts and thus illegal. Although the Democrats forced changes to the Act on this point, at least one legal opinion is that the Act's threat to these forms of action remains. Moreover, where two or more union members are involved in a civil protest, the union is deemed to be involved unless it proves the contrary. These provisions appear to be aimed directly at the waterfront unions, although it also appears to have caught Transport workers, and perhaps others.

\section{Unions (Part IX)}

The first package proposed sweeping changes to the rights and structures of unions or, in the Acts' preferred terminology, 'registered organizations'. The package was steadfastly opposed to what is termed compulsory unionism, and intended to encourage inter union competition by removing the 'conveniently belong' rule. According to this rule the AIRC assigned workers to unions according to what work the members did, and if an existing union could 'conveniently' represent such workers. The original package also permitted the formation of enterprise unions, with as few as 20 members, the disamalgamation of the large 'super unions' built up after 1987 (following the amalgamation program of the ACTU and the ALP) and the capacity of union branches/ sections to act relatively independently from their central body. The original package also prohibited unions' automatic right of entry to workplaces unless by a 
worker's specific written invitation. In workplace negotiations, union representatives would have to be able to show that employees had authorized them to act on their behalf.

The final act differs significantly. It does not remove union representation rights, but does dilute them, by allowing the registration of small, enterprise unions (or 'registered organizations'). However, the registration of these unions (now, with a minimum of 50 members), may be contested by established unions under the 'conveniently belong' rule, which has not been removed. The restrictions on unions' 'right of entry' to workplaces have also been relaxed, although some commentators have criticized the system as too bureaucratic, since it involves complex arrangements that issue a kind of 'pass' for union delegates to enter the workplace. Union (or non union) representatives will still have to be authorized by employees, but the Democrats insisted that workers be informed of the right to such representation beforehand, and that employers be required to deal with such an authorized representative. Unions have retained the right to investigate breaches where union members are employed. The Objects of the Act have been amended to allow the effective functioning of unions, but the actual provisions of the Act - in particular those that place the onus on employees to invite union participation in bargaining -- will undoubtedly impede it. In addition, one of the most potentially influential aspects of the Act is section 170LK (Part IX, Div 3), which allows an employer to bypass unions and directly approach workers at the bargaining stage, and potentially to offer inducements to leave unions and the award system in favour of AWAs. Finally, the focus on individual rights has significantly strengthened the ability of workers to decline union membership under the freedom of association provisions. In this it follows the British model (Wedderburn 1989)

\section{Unfair Dismissal (Part VIA, Div 3)}

Labor's unfair dismissal provisions have been deleted from the Act; indeed, the High Court in November 1997 ruled them unconstitutional on the basis that they represent an inappropriate use of the External Affairs powers of the Constitution. The new Act is based on a 'fair go all round' test in contrast to the application of procedural fairness under the former legislation. The new test requires the AIRC to consider the circumstances of the employer in assessing unfair dismissal and relevant redress. Compensation has been marginally raised (from $\$ 30,000$ to $\$ 32,000$ ), however the new test is likely to severely constrain this option. It is a significant shift in favour of the employers' prerogatives to hire and fire and will almost certainly fuel the casualization of the labour force. Further 
employer pressure has seen the coalition attempt, in 1997, to deny access to these provisions for workers in firms employing less than 50 people.

\section{Junior Pay Rates and the Training Wage}

The original package proposed that junior pay rates continue without any consideration of 'equal pay for equal work' arguments. Labor had proposed that the system of junior and training wage rates (which it had put in place) be reviewed after three years in a major test case in the AIRC. The Democrats insisted the latter position be reflected in the new Act. As to the training wage, the Liberals' original package proposed that trainees' or apprentices' wages could be reduced according to the mix of work and training agreed under an AWA or CA and under the Liberals' new training system, 'MAATS' (Modern Australian Apprenticeship Training System). Activity defined as training would not be paid for by the employer. But this would have given too much power to the employer to define menial work as training, and thus not pay for it (the apprentices' wages would be topped up by the state to the youth allowance rates). The proposal of the Democrats is that the determination of the mix of paid work and training, insofar as it affects wages, be supervised by the Employment Advocate and/or the AIRC, especially to ensure that the training given is properly accredited in the terms of the National Qualifications Framework (NQF). The final form of the training system is not known at the time of writing, since it is tied up with efforts (once again held up in the Senate) to remove youth eligibility for unemployment benefits, and a range of other benefits, and substitute a minimal 'youth allowance'. The intention is to force young people into longer periods of schooling and training, supported by their families, and thereby removed from the unemployment statistics.

\section{UNION STRATEGY, WAGES POLICY AND THE 'LIVING WAGE'} CLAIM

The main strategic challenge for the union movement was to adjust to the new realities of exclusion from at least the trappings of influence on government. A report on the ALP election loss placed considerable blame on the Accord in combination with the ALP's implementation of economic liberal policies that hurt ordinary workers, who then left unions and/or voted for the Coalition (Federal Campaign Consultative Panel 1996). The report follows widely reported survey evidence which found high levels of dissatisfaction with unions' performance in protecting workers against work intensification and stress (also see DIR 1995, 1996). The report argues that despite claims about union influence on public policy, 
ordinary members had little chance to influence the decisions taken by senior union officials, but nevertheless suffered the consequences in the form of low wages, reduced conditions and increased employment insecurity (Federal Campaign Consultative Panel 1996). The report was a major embarrassment to the ALP leadership, present and past, and to the ACTU. It questions the future of relations between the ALP and the ACTU, and the possibility of any future Accord. Both sides are non-committal, and have insisted that more policy autonomy for each be maintained.

Prior to the passage of the Workplace Relations Act, the union movement mounted a scare campaign -- perhaps justifiably in view of the threats embodied in the early proposals. Another strategy was to try to persuade employers to sign agreements that bound them to preserve award and other entitlements, and effectively to abjure the use of whatever powers the new Act would give employers. The ACTU also asked the Commission to adopt a new set of wage fixing guidelines declaring "non discriminatory wages and conditions" as one of its fundamental principles. This would prevent employers offering financial incentives to employees to leave unions and award coverage in favour of staff conditions and individual contracts. This controversial issue was highlighted in a continuing case over the use of individual contracts by CRA Ltd in the mining industry (particularly at Wiepa bauxite mine in Queensland). The AIRC found (Print No. M8600: 44-52) that under s. 170ND(5) of the Industrial Relations Act, 1993 - which inter alia prohibits discrimination in wages and conditions on the basis of union membership - that the company had discriminated against its employees who chose to be represented by the union and remain on award conditions. Not surprisingly the ACTU is asking the Commission to make it an overall wage fixing principle. Naturally, the move is resisted by employers.

Another key union strategy was to mount a so-called 'living wage' case before the AIRC. The claim, in essence, aimed to emphasize social and equity considerations in wage fixing. Ironically, under the former Labor administration, the ACTU had increasingly downplayed such considerations, effectively subordinating wage policy to perceived national economic requirements. As some commentators have pointed out, the ACTU is now relying on arguments about the wage dispersion effects of enterprise bargaining that it found uncomfortable in the last years of the Accord. But with the end of the Accord, the ACTU now professes itself unconcerned with macro-economic policy - as ACTU President Jennie George said "the ACTU no longer accepts any responsibility in terms of macro-economic outcomes - that's the Government's job" (Australian Financial Review, 12/12/96). However, the outcome of this position is that the Reserve Bank has taken an increased role in wage determination, 
based on its newly reaffirmed independence from government, and its heightened role in a deregulated economic environment via its control over interest rates. The Governor of the Reserve Bank has repeatedly threatened the use of monetary policy to restrain demand, lest wage settlements threaten the Bank's inflationary targets.

The Living Wage Case, launched before the Commission on December 4, was a highly public forum for the ACTU to restate its credentials as a defender of workers' interests. It also symbolized a return to the basic principles of Australian wage fixing - that wages should enable a person to have access to the necessities of life. Thus, much of the ACTU's evidence showed that award wages of the lowest paid are insufficient to provide such necessities. The phenomenon of 'waged poverty' is emerging, and with it a class of 'working poor', who, although in employment, are living at or below the 'poverty line'. The ACTU's claim was for arbitrated pay increases of $\$ 20$ per week, for each of the next three years, for workers who do not receive pay increases through enterprise bargaining. It also wanted the AIRC to increase minimum award rates for the lowest paid entry level jobs (currently around $\$ 350$ to $\$ 390$ ) to $\$ 456$ over the next three years. All other minimum award rates would move to maintain relativities. This would increase all minimum award rates by 8.75 percent on average per year for each of the next three years, giving a total wage rise of nearly 30 percent.

The ACTU argued that the increases in minimum rates should be 'absorbed' into any existing over award payments, thus restricting them to the lowest paid. A flaw in this argument was always that some highly paid workers simply have high award rates, and do not receive over-award payments - thus the increase may not be limited to the low-paid, compromising its equity claims. Apart from this, controversy over the claim concerns its size and its macroeconomic effects. The ACTU has argued that the claim will add only "1 percent or less" to the national wages bill, which is within Reserve Bank guidelines for wages growth and is thus affordable, with no loss of jobs. However, the ACTU found itself with few supporters before the Commission. Most submissions rejected the ACTU claim; the federal government (which argued for an $\$ 8$ rise); the Business Council (which argued for a single minimum wage); and even the ALP(!), which argued for a lower claim of $\$ 15$. The latter is close to the last Accord agreement of early 1996. Thus it was not surprising that the Commission's decision would not "link the level of the Federal Minimum Wage with any defined benchmark of needs", and gave credence to Reserve Bank concerns about the likely inflationary effects of the claim. The final ruling, a "bitter disappointment" to the ACTU, was for a flat \$10 pay increase for 
workers on minimum award rates of pay, effectively setting a new minimum wage of $\$ 359.40$ per week (The Australian, 23/4/97).

\section{INDUSTRIAL RELATIONS FLASHPOINTS}

As soon as the government's reform intentions were announced, certain industrial relations flashpoints, where industrial action is likely, were revealed. The most significant of these are as follows. First, the government has indicated its determination to reform the waterfront, by pointing to what it sees as deficiencies in terms of productivity, for which it blames the unions and work practices they defend. According to the government, it is crucial to eliminate these if international competitiveness is to be achieved in many industries. The key to waterfront reform, for the government, is the greatly increased powers the new Act delivers to employers. On the other hand, the strength of the Australian waterfront unionism has been in the scope of its coverage. The Waterside Workers' Federation has maintained virtually 100 percent union density in all Australian publicly owned ports since state regulation of the industry first began during WWII. Union amalgamations under the ACTU 'industry unionism' strategy created the Maritime Union of Australia (MUA) in 1993. With some 8,000 members in this strategic industry it is one of the strongest unions in the country.

As in the case of ports around the world, technological change saw a fall in waterfront employment from a high of 28,000 to less than 4,000 by the early 1990s (which already included other workers). Along with technological change came an increasing concentration in the industry. The Coalition preference is to remove the barriers to entry for new stevedoring companies, port operations and shipping services. It sees the MUA as a critical blockage and will no doubt be keen to test the WRA in respect to new operators. At the moment, certain powerful unions have entered pacts to support each others' interests. Many employers have indicated that they are reluctant to be the first to use the new powers for fear of retribution from the existing strong unions. It may be the government that performs that function, perhaps following the British model and initially encouraging private ports (and the privatization of ports) to undermine the MUA. It should be noted that it took the British Conservative government ten years to directly dismantle the Dock Labour Scheme (Turnbull et al. 1992).

Second, there will clearly be further industrial relations instability in the coal industry, as key mining companies, led by the major mining firm Rio Tinto (formerly CRA, or RTZ/CRA) are determined to break union control over work practices, and to put their employees on indi- 
vidual contracts. Unions are just as determined to resist this challenge to their recognition. Unions in the coal industry are among the most militant in the country - they have had to be to protect themselves against employer laxness over safety. Industrial unrest could be quickly transmitted to the waterfront, or indeed from the waterfront to the coal industry, given the agreement between the Construction, Forestry, Mining and Energy Union (CFMEU) and the MUA to band together to resist attacks by employers. A study commissioned by RTZ/CRA, a major mining firm at the forefront of deunionization, was reported to have found that there was little 'flexibility' in the black coal industry, since bargaining was conducted at industry level, rather than at the enterprise. Therefore, the industry was lagging in its attempts to introduce reforms carried out in other industries. Another government inquiry adds to the pressure on the union. Both inquiries, not surprisingly, find that there is less part-time and casual employment in the black coal industry, and more reliance on overtime, paid at high penalty rates, when compared even with other sectors of mining. Clearly this is another area where the new industrial relations legislation is to be tested.

Third, another focus of the government's concern is the public service. The government has made significant changes to top personnel in key departments, appointing preferred administrators and removing Labor appointees. Almost half of department heads have left the service since Labor lost office last year. It has put a former Liberal economics adviser (Dr. David Boxall) in charge of the Department of Finance. This department is central to the budget review process, and Boxall was a central player in developing the Coalition's economics manifestos for the 1990 and 1993 elections (both of which the Coalition lost, in part because of the extremism of its economic policy!). Thus analysts expect job shedding in the public sector to increase. Countering this, the Community and Public Sector Union (CPSU) is preparing for a battle with the government over job security. On the other side, the government has indicated its intentions to cut 'unnecessary costs' in the public sector, in particular administrative procedures, to broaden public service job classifications, move to performance-based pay and greatly decentralize industrial relations in the sector. The government is also going to use the public service as a key testing ground for some of the provisions of its new Workplace Relations Act. For instance, the government has indicated that it will penalize employees who undertake industrial actions like 'work-to-rule', or other restrictions of output. The new Act makes prosecution much easier - indeed mandatory. For some time, low-level industrial action has been occuring in the public service in protest over the government's reforms. An example of such action is refusing to col- 
lect fees for government services. To counteract such action, Minister Reith has indicated that employees who do not fulfill the full range of their duties will not be paid. Indeed, the new Act makes it illegal for employers to pay employees who are engaged in any form of industrial action, not just those on strike. The government was also considering ending the practice of union dues being automatically deducted from workers' salaries by the Commonwealth agencies paying them. Naturally, the CPSU condemned both moves, and denied that its campaign would be affected by them.

A fourth area of concern is trade and employment policy, and the associated emergence of the radical Right. Since much of manufacturing industry is still chronically uncompetitive, government cutbacks and other measures exacerbate the unemployment problem while failing to improve domestic industrial capacity to the point where it can meet more of domestic demand as growth increases, thus denying it to imports. Thus much attention has been focussed on Australia's trade and industry policies. Assistance to industry has been reduced, and tariff reductions are continuing. However, this raises the question of 'reciprocity', especially in the agricultural sectors of Australia's trading partners, particularly Japan, Korea and the US. The issue appeared to be quietly defused at the recent World Trade Organization (WTO) summit in Singapore, as Australia pushed for tariff reductions to be extended to the protected agricultural sectors, but failed to gain much beyond the usual vague assurances. At the same time, Australia has been subjected to the threat of sanctions through the WTO, as American industrial interests question the legality of Australian industrial plans in the auto, textile, clothing and footwear industries, and protective measures against the importation of Canadian salmon. There is no doubt that the existing WTO rules discriminate against agricultural producers like Australia, by not challenging agricultural protection in countries like Japan, Korea, the US and the European Union. In Australia, there are therefore signs of a shift in the hitherto unchallenged political consensus around the virtues of world trade integration and tariff reductions that was a hallmark of the Labor years, if not those of the preceding Liberal/National Coalition. This might take Australian politics into uncharted waters.

One of these signs is the drift of its hitherto core support from the Labor party to the Liberals and to other new political coalitions. This is the core 'working class' support that was damaged under Labor's rule, seemingly by policies that Labor put in place, especially tariff reduction, financial deregulation and industrial relations reform. The loss of the electorate of Oxley, formerly a core Labor working-class district, to an independent previously expelled from the Liberal party for expressing 
racist views, is symbolic. Hanson, and the new 'One Nation' party she has founded, has become a rallying point for a wide spectrum of casualties of economic change, some of which are prone to simplistic xenophobic explanations for their plight. These elements also attract support from rural casualties of globalization, many of them constituents of the National Party, the Liberal's coalition partner and base for the Deputy Prime Minister and Trade Minister Fischer. Another sign of political drift from the 'consensus' around tariff reduction is the unease expressed by backbenchers of the National party. This could lead the government to relent on tariff reductions, and return in a sense to patterns of the Fraser years (1975-1983), when the zeal to reduce tariffs was tempered by the electoral consequences of the resulting unemployment. These currents are evidence of the reversion of Australian politics to patterns established at its inception - tariff protection and racial immigration policy.

\section{CONCLUSION}

This article has described the key developments in Australian industrial relations since the change of government, setting these against the longer and shorter term backgrounds, and suggested that, although significant, they do not add up to fundamental transformation in Australian industrial relations. The most dramatic indicator of fundamental change was the exclusion of unions from influence with the government following the collapse of Australia's 'corporatist' arrangements. Once again, a more subtle reading establishes that the erstwhile corporatist arrangements actually oversaw the implementation of liberal economic policies, so the accession to power of Labor's political opponents, with the policy stance they represent, was simply a logical next step down the liberal economic road Labor had already taken. Thus there is more continuity with Labor's industrial relations arrangements than appears at first glance, especially since the peak union leadership largely accepted the Labor government's liberal economic stance. On the other hand, union pressure within the Labor party prevented the extremes of the ALP Leadership's proposals to reform industrial relations, in particular to simplify the award system. Perhaps the area of most important change concerns the mechanisms of union recognition and representation. The Liberal/ Coalition government has made it easier for employers to use non-union agreements and individual contracts with employees, and it can therefore be expected that the unionized sector of the economy will contract. But if this occurs, as seems likely, it will not solely be the result of the Liberal's actions, since the ALP/ACTU axis prepared the ground for it. 


\section{】 REFERENCES}

AIRC. 1991a. National Wage Case Decision. April. Print J7400.

AIRC. 1991b. National Wage Case Decision. October. Print K0300.

AIRC. 1996. Weipa Decision. Print M8600.

ARCHER, R. 1992. "The Unexpected Emergence of Australian Corporatism." Social Corporatism: A Superior Economic System? J. Pekkarinen, M. Pohjola and B. Rowthorn, eds. Oxford: Clarendon, 377-417.

ARCHER, R. 1995. Economic Democracy. Oxford: Clarendon.

Australian BuREAu OF STATISTICS (ABS). 1996. Trade Union Members, Australia. Cat. No. 6325.0.

BEAN, R. 1994. Comparative Industrial Relations: An Introduction to CrossNational Perspectives. 2d ed. London: Routledge.

BEILHARZ, P. 1994. Transforming Labour: Labour Tradition and the Labour Decade in Australia. Melbourne: Cambridge University Press.

BERRY, P. and D. KITCHENER. 1989. Can Unions Survive? Melbourne: BWIU.

BLANDY, R. and J. NILAND. 1986. Alternatives to Arbitration. Sydney: Allen and Unwin.

BUSINESS COUNCIL OF AUSTRALIA (BCA). 1989. Enterprise Based Bargaining Units: A Better Way of Working. Melbourne: BCA.

CALluS, R. et al. 1991. Industrial Relations at Work: The Australian Workplace Industrial Relations Survey. Canberra: AGPS.

CASTLES, F. 1985. The Working Class and Welfare: Reflections on the Political Development of the Welfare State in Australia and New Zealand. Wellington, NZ: Allen and Unwin.

CASTlES, F. 1988. Australian Public Policy and Economic Vulnerability. Sydney: Allen and Unwin.

DABSCHECK, B. 1989. Australian Industrial Relations in the 1980s. Sydney: Oxford University Press.

DABSCHECK, B. 1994. "The Arbitration System Since 1967." State, Economy and Public Policy in Australia. S. Bell and B. Head, eds. Melbourne: Melbourne University Press.

DABSCHECK, B. 1995. The Struggle for Australian Industrial Relations. Sydney: Oxford University Press.

DAVIDSON, R. 1992. "The Failures of Financial Deregulation in Australia." Business-Government Relations in Australia. S. Bell and J. Wanna, eds. Sydney: Harcourt Brace Jovanovitch.

DIR (DEPARTMENT OF INDUSTRIAL RELATIONS). 1995. Annual Report 1994: Enterprise Bargaining in Australia: Developments Under the Industrial Relations Reform Act. Canberra: Australian Government Publishing Service. 
DIR (DEPARTMENT OF INDUSTRIAL RELATIONS). 1996. Annual Report 1995: Enterprise Bargaining in Australia: Developments Under the Industrial Relations Reform Act. Canberra: Australian Government Publishing Service.

EDWARDS, J. 1996. Keating: The Inside Story. Australia: Penguin.

EvatT Foundation. 1995. Unions 2001: A Blueprint for Trade Union Activism. Sydney: Evatt Foundation.

EwER, P., I. HAMPSON, C. LlOYD, J. RAINFORD, S. RIX, and M. SMiTH. 1991. Politics and the Accord. Sydney: Pluto.

Federal CAmPaign Consultative Panel. 1996. Draft Report. Australian Labor Party, New South Wales Branch.

FELS, G. and G. FUERSTENBERG. 1989. A Supply-Side Agenda for Germany: Sparks from the United States. Berlin: Springer Verlag.

GRAHL, J. and P. TEAGUE. 1989. "Labour Market Flexibility in West Germany, Britain and France." West European Politics, Vol. 12, April, 91111.

HAMPSON, I. 1996. "The Accord: A Post-Mortem." Labour and Industry, Vol. 7, No. 2, 55-78.

HANCOCK, Keith and Joe ISAAC. 1992. "Australian Experiments in Wage Policy." British Journal of Industrial Relations, Vol. 30, No. 2, 213-236.

HANCOCK, Keith and Don RAWSON. 1993. "The Metamorphosis of Australian Industrial Relations." British Journal of Industrial Relations, Vol. 31, 489-513.

Katzenstein, P. 1978. Between Power and Plenty: Foreign Economic Policies of Advanced Industrial Societies. Madison: University of Wisconsin Press.

KatZenstein, P. 1985. Small States in World Markets. Ithaca: Cornell University Press.

Kelly, P. 1994. The End of Certainty: Power, Politics and Business in Australia. 2d ed. Sydney: Allen and Unwin.

KYLOH, R. 1989. "Flexibility and Structural Adjustment through Consensus: Some Lessons from Australia." International Labour Review, Vol. 128, No. 1.

KYLOH, R. 1994. "Restructuring at the National Level: Labour-led Restructuring and Reform in Australia." Creating Economic Opportunities: The Role of Labour Standards in Industrial Restructuring. W. Genberger and D. Campbell, eds. Geneva: International Institute for Labour Studies.

MATTHEWS, T. 1994. "Employers' Associations, Corporatism and the Accord." State, Economy and Public Policy in Australia. S. Bell and B. Head, eds. Melbourne: Melbourne University Press. 
MCCALlum, J. 1993. "Enhancing Federal Enterprise Bargaining: The Industrial Relations Legislation Amendment Act 1992, Cth." Australian Journal of Labor Law, Vol. 6, No. 1, 63-68.

MACINTYRE, S. 1986. "Labour, Capital and Arbitration 1890-1920." State and Economy in Australia. B. Head, ed. Melbourne: Oxford University Press.

NIELSEN, K. 1991. "Towards a Flexible Future? Theories and Politics, Introduction." The Politics of Flexibility. B. Jessop et al., eds. UK: Edward Elgar.

O'BRIEN, J. 1994. "McKinsey, Hilmer and the BCA: The 'New Management' Model of Labour Market Reform." Journal of Industrial Relations, Vol. 34, No. 2, 468-491.

ORGANIZATION FOR ECONOMIC COOPERATION AND DEVELOPMENT (OECD). 1986. Labour Market Flexibility. Paris: OECD.

PEETZ, D. 1996. "Unions, Conflict and the Dilemma of Cooperation." Journal of Industrial Relations, Vol. 38, No. 4, 548-570.

Plowman, D. H. 1992. "An Uneasy Conjunction: Opting Out and the Arbitration System." Journal of Industrial Relations, Vol. 34, No. 2, 284306.

PUSEY, M. 1991. Economic Rationalism in Canberra: A Nation-Building State Changes Its Mind. Sydney: Cambridge University Press.

RAVENHILL, J. 1994. "Australia and the Global Economy." State, Economy and Public Policy in Australia. S. Bell and B. Head, eds. Melbourne: Melbourne University Press.

STILWELL, F. 1986. The Accord: And Beyond. Sydney: Pluto.

TURnBUll, Peter, C. WoOlFSON and J. KELlY. 1992. Dock Strike: Conflict and Restructuring in Britain's Ports. Aldershot: Avebury.

WARHURST, J. 1982. Jobs or Dogma. St. Lucia: University of Queensland Press.

WEDDERBURN, Lord. 1989. "Freedom of Association and the Philosophies of Labour Law." The Industrial Law Journal, Vol. 18, No. 1, 1-38.

YATES, C. 1996. "Neo-Liberalism and the Working Girl: The Dilemmas of Women and the Australian Trade Union Movement." Economic and Industrial Democracy, Vol. 17, 627-665.

\section{RÉSUMÉ}

Continuité et changements récents dans les relations industrielles en Australie

En Australie, au cours des années 1980, l'Australian Labor Party (ALP), gouvernement officiellement socialdémocrate, a mis en place des 
réformes de libéralisation économique et une réforme des relations industrielles motivée par le concept de flexibilité du marché du travail. La haute instance syndicale, l'Australian Council of Trade Unions (ACTU), a consenti à la plupart des changements proposés en signant un accord négocié avec l'ALP, Toutefois, ce lien syndical-gouvernemental a empêché l'APL d'appliquer les mesures radicales visant la flexibilité du travail, surtout après la récession du début des années 1980. Le gouvernement conservateur (coalition libérale-nationale) qui a pris le pouvoir en mars 1996 a promis d'apporter des changements importants aux relations industrielles australiennes, peut-être même de les transformer. La conclusion de l'accord entre l'ACTU et l'ALP a enlevé aux syndicats toute influence directe sur la politique publique. Cependant, les éléments clés de l'ensemble des réformes du gouvernement conservateur avaient été annoncées et même partiellement mis en place par le gouvernement de l'ALP. On constate donc une certaine continuité dans les politiques des gouvernements qui se sont succédé. Par ailleurs, ces politiques comportent des éléments de changement importants, dont certains sont susceptibles de miner fortement le pouvoir des syndicats.

L'appui exprimé par les membres influents du nouveau gouvernement en faveur d'une réforme du marché du travail s'alignant sur celle des États-Unis ouvre la porte à des changements radicaux (réduction des salaires, diminution du filet de sécurité sociale et rôle fortement amoindri des syndicats et de la réglementation sur le travail). Le nouveau gouvernement a donc donné force de loi à une série d'amendements apportés à la législation régissant les relations industrielles australiennes. Toutefois, plusieurs facteurs ont empêché l'entière application de ces mesures. Premièrement, la constitution fédérale de l'Australie accorde un rôle à la législation fédérale en matière de relations industrielles, rôle assumé par une institution clé : l'Australian Industrial Relations Commission (AIRC). En effet, en Australie, la majorité des conditions salariales et clauses normatives sont encore régies par les décisions ayant force obligatoire rendues par l'AIRC. Deuxièmement, toute nouvelle loi, même lorsqu'elle a reçu un net appui à la Chambre des représentants, doit encore être approuvée par le Sénat, chambre haute d'examen des lois. Aux cours de toutes les étapes d'élaboration et d'approbation, la nouvelle Workplace Relations (and other) Amendment Act n'a cessé d'être adoucie pour obtenir l'appui des petits partis. Troisièmement, à l'occasion de la dernière élection fédérale, le premier ministre candidat a promis que ses réformes en matière de relations industrielles sauvegarderaient le niveau des salaires et les conditions de travail du moment. Pour conserver la faveur de l'électorat, cette promesse ne peut être battue en brèche trop ouvertement, et, de toute façon, les petits partis ont veillé à ce qu'elle soit reflétée 
dans la loi. Finalement, les travailleurs et les syndicats ont été beaucoup moins touchés que ne le laissaient présager les premières ébauches de cette loi.

La nouvelle loi facilite la négociation d'ententes patronales-syndicales non soumises aux décisions de l'AIRC, sans toutefois les en affranchir complètement, car elles doivent réussir le test du "no disadvantage ", c'est-à-dire respecter les conditions minimales établies par la décision pertinente. Contrairement à ce qui avait été proposé, la confidentialité et le non-examen de ces ententes n'ont pas été retenus. En second lieu, la nouvelle loi réduit le pouvoir des syndicats et de l'action collective de bien des manières, notamment en imposant des pénalités plus sévères en cas de second boycottage, en ouvrant plus grand la porte à la concurrence intersyndicale et en permettant la formation de nouveaux syndicats composés de 50 membres seulement. Troisièmement, elle facilite aux employeurs le recours rapide à des actions en justice contre les travailleurs qui poursuivent des actions illégales dans leur milieu de travail malgré l'ordre reçu de l'AIRC de cesser ces actions. Quatrièmement, bien que la loi ne permette plus le recours fondé sur les procédures du travail en cas de congédiement jugé injuste, elle conserve néanmoins la prescription relative au recours fondé sur le critère d'« une dernière chance à accorder ", autant pour les employeurs que pour les employés. Cinquièmement, elle assouplit l'utilisation par l'employeur de la rémunération de formation. Tous ces changements laissent entrevoir une plus grande flexibilité du marché du travail.

Le mouvement syndical australien, dirigé par l'ACTU, s'est heurté à des difficultés dans sa réaction au nouveau régime. Dans un cas important concernant le salaire minimum vital, l'ACTU a eu recours à la Commission et lui a demandé d'accorder une augmentation salariale (prime versée par le régime) par le moyen d'une hausse du filet de sécurité pour les travailleurs les moins biens rémunérés et incapables d'obtenir des augmentations salariales par la négociation avec l'entreprise. L'ACTU a soutenu que les salaires, dans certains secteurs, avaient chuté à un niveau n'assurant plus une existence convenable aux familles qui en dépendaient. L'ACTU a effectivement ressorti le principe de la détermination salariale fondée sur les besoins, qui était né à l'aube des relations industrielles australiennes au tournant du siècle. Cependant, la libéralisation du système financier de l'Australie a accentué l'incidence des salaires sur la stabilisation économique, et la banque centrale a menacé de hausser les taux d'intérêts si l'augmentation salariale était accordée. La détermination de la Commission à approuver une augmentation salariale minimale a reflété les nouvelles réalités des relations industrielles 
australiennes, mais surtout l'influence de la banque centrale sur les salaires par sa mainmise sur les taux d'intérêt.

Bien des changements survenus dans les relations industrielles en Australie prendront un certain temps avant de se frayer un chemin dans le système, principalement en raison de la contestation de la constitutionnalité de certaines mesures devant la plus haute cour du pays. Le rythme des changements ne sera donc pas celui du big bang espéré par les uns et craint par les autres. Dans le domaine des relations industrielles, il est clair cependant que la nouvelle loi fait pencher la balance du côté des employeurs en ce qui a trait au pouvoir. Un certain militantisme de la part des employeurs se manifeste dans l'industrie du charbon, sur les quais des débardeurs et dans le secteur public, bien que les employeurs du secteur maritime devront se plier aux décisions gouvernementales. Les changements survenus en 1996 dans les relations industrielles en Australie affichent donc un certain degré de continuité malgré le fait qu'ils peuvent paraître passablement fondamentaux.

\section{RESÚMEN}

\section{Continuidad y cambio en las relaciones industriales en} Australia : Desarrollos recientes

La reciente obtención del poder de la parte del partido conservador (Coalición Liberal / Nacional) en Australia representa un cambio, quizás una transformación, en las relaciones industriales en Australia. Sin embargo una lectura mas lógica de los eventos nos permite ver que los elementos clave del plan de reformas del gobierno fueron ya sea implementadas o cuando menos avanzadas por el gobierno saliente del partido australiano laboral. Este ultimo era conocido por su entusiasta implementación de políticas económicas ortodoxas, dentro de un contexto de tipo corporativo. Esto sugiere un grado de continuidad entre las políticas del primero y el segundo partido. Al mismo tiempo, existen ingredientes de importante cambio, algunos de apariencia pequeña, pero a través del tiempo tenderán a debilitar la fuerza de los sindicatos y así aumentar las diferencias entre los sectores sindicalizados y los no sindicalizados. 